\title{
ABOLISHED AND FORGOTTEN NATIONAL GRASSLAND PARKS
}

\author{
by C. STUART HOUSTON ${ }^{1}$
}

My old 3-mile-per-inch topographical map of the Maple Creek area included an area blocked in as Menissawok Park. I had forgotten this until David A. E. Spalding reprinted in the September 1973 Alberta Naturalist, under the heading "Where are they now?", a Dominion Order-inCouncil dated 31 May, 1922, setting up three Dominion Parks. These were as follows:

Menissawok Park of 17 square miles, a nearly rectangular area beginning just five miles south of Maple Creek, Saskatchewan. Menissawok is a Cree word meaning "many berries".

Nemiskam Park of $8-1 / 2$ square miles, beginning three miles north of the hamlet of Nemiskam, Alberta.

Wawaskesy Park of over 54 square miles, beginning 28 miles north and 4 miles east of Medicine Hat, Alberta, within a local elbow of the South Saskatchewan River. Wawaskesy is a Cree word meaning "red deer".

I knew from a paper by J. Dewey Soper, "Notes on the fauna of the former Nemiskam National Park and vicinity, Alberts" (Can. Field-Nat. 63: 167-182, 1949), that "this park was cancelled by legislation adopted during the 1946-47 session of Parliament". But why was Nemiskam Park abolished and when were the other two discontinued? With the Saskatchewan Natural History Society advocating a National Grasslands Park, shouldn't we learn what hap-

1863 University Drive,

Saskatoon, Saskatchewan.

S7N $0 J 8$. pened to the three smaller parks $w$ once had?

Since both governments are in volved in the formation of nationa parks, I wrote first to W. Schwart Controller of Surveys in the Saskat chewan Department of Natura Resources. My questions were not eas to answer. After a month of searching T. F. Wagner, Supervisor of Land reported that "very little informatio could be found". He confirmed tha Order-in-Council No. 1134 had bee published as a Proclamation in th Canada Gazettes of July 1, 8 and $15 n$ 1922. His staff had made a check o the Canada Gazettes between 192. and 1934 and could find no referenc specifically rescinding the Order-in Council creating these parks. Mr Wagner commented: "It is difficult to believe that the land would have bee turned over to the Province as long a it had Dominion Park status, unles the transfer automatically rescindec such reserves or if a rescinding O.C was not published in the Canad: Gazette, both of which seem unlikely Frankly, I really don't know where the information as to when and why this park was eliminated can be found."

Mr. Wagner kindly provided a copy of P.C. 1164-1/2, dated 7 August 1931 , by which $7-1 / 4$ of the 17 sections of land in Menissawoik Park were transferred to the Province of Saskatchewan, and suggested that the remainder was transferred to the Province under the Resources Transfer Agreement of 20 March, 1930. Since then, the former Menissawok 


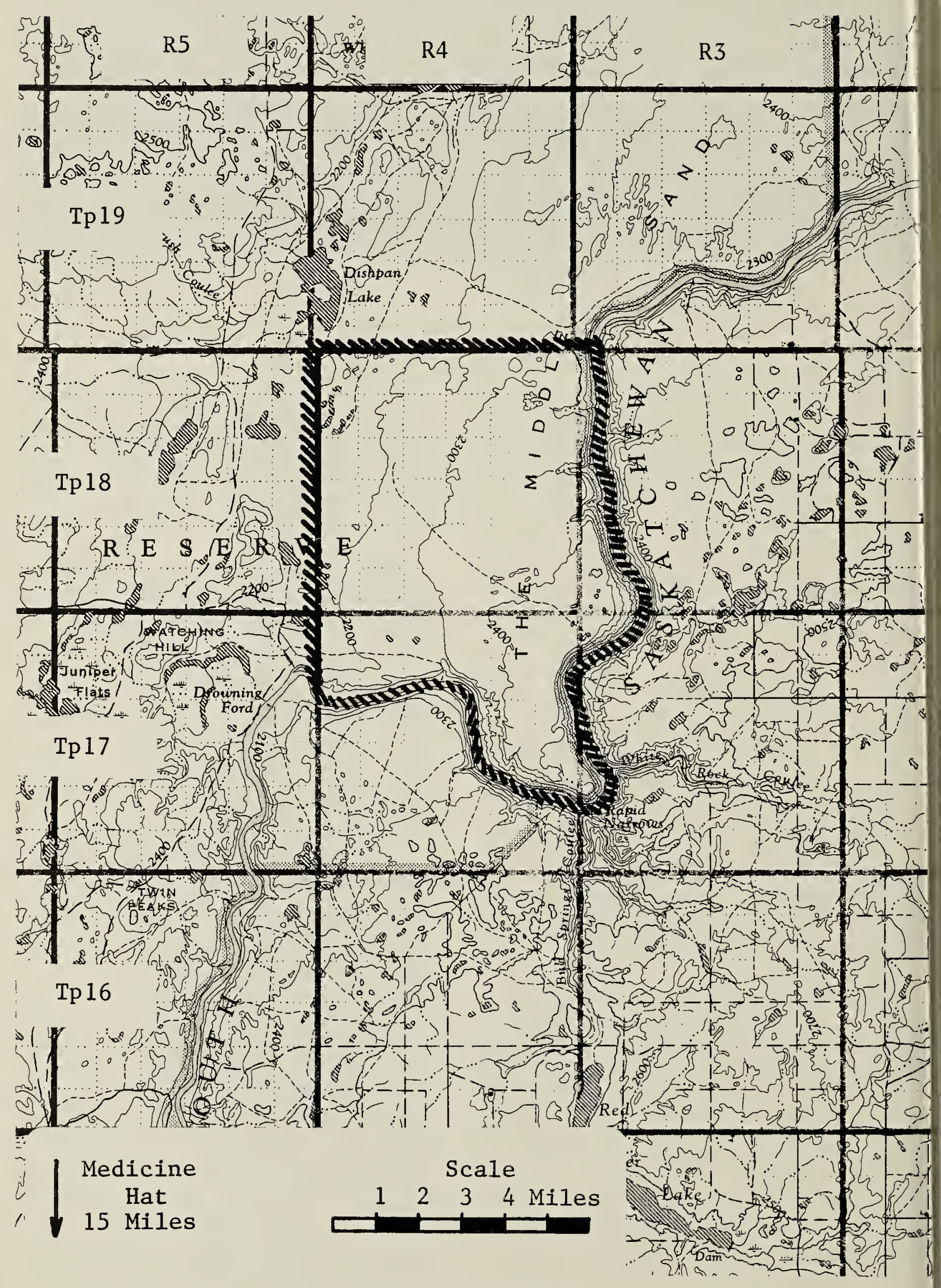

1. Wawaskesy, Alberta 
FORMER NATIONAL PARKS

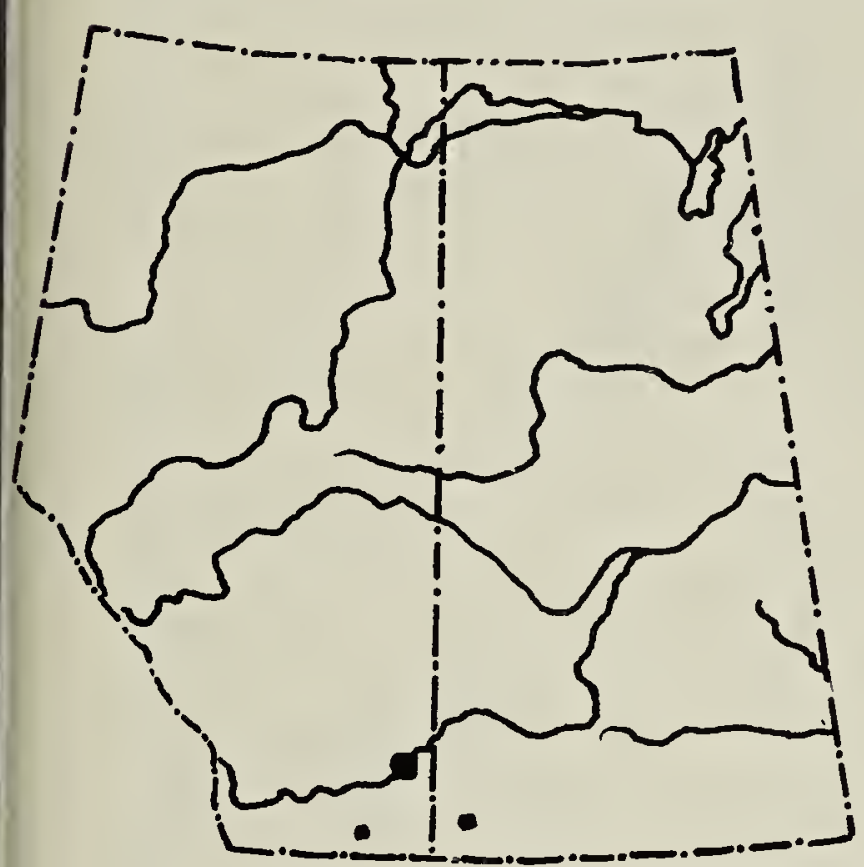

1. Wawaskesy National Park

2. Nemiskam National Park

3. Menissawok National Park
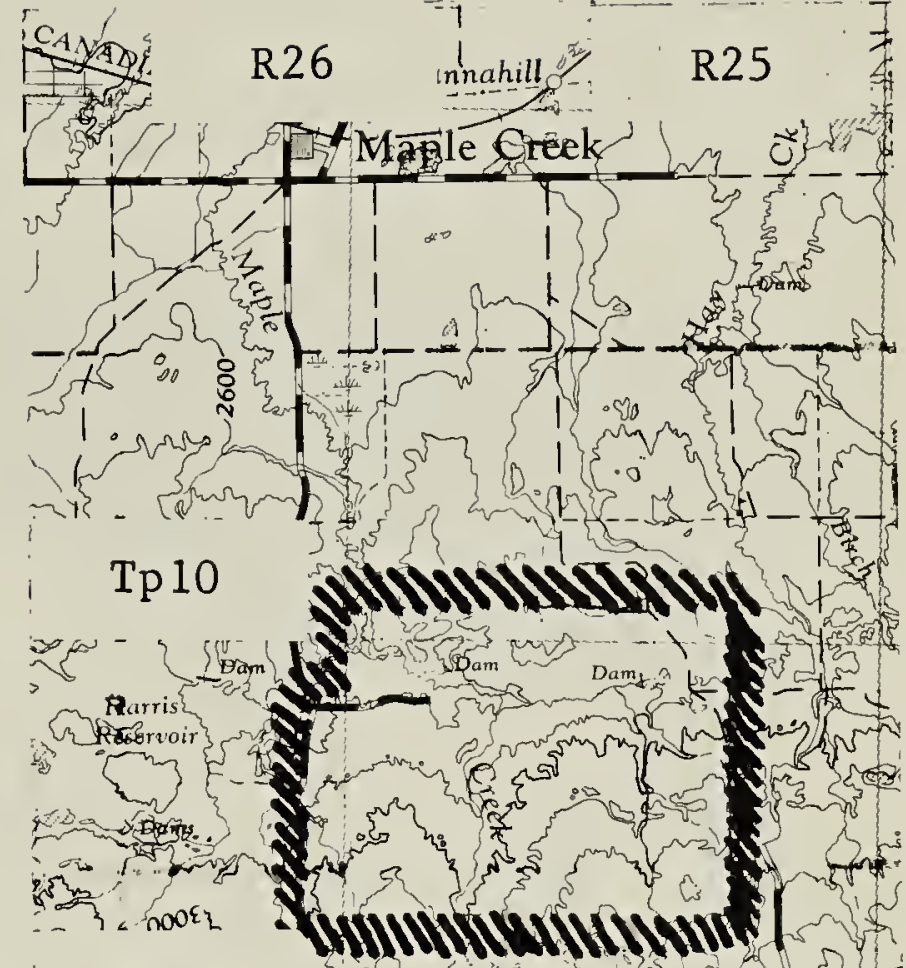

Tp9 है

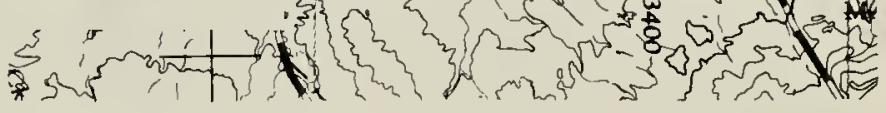

3. Menissawok, Saskatchewan

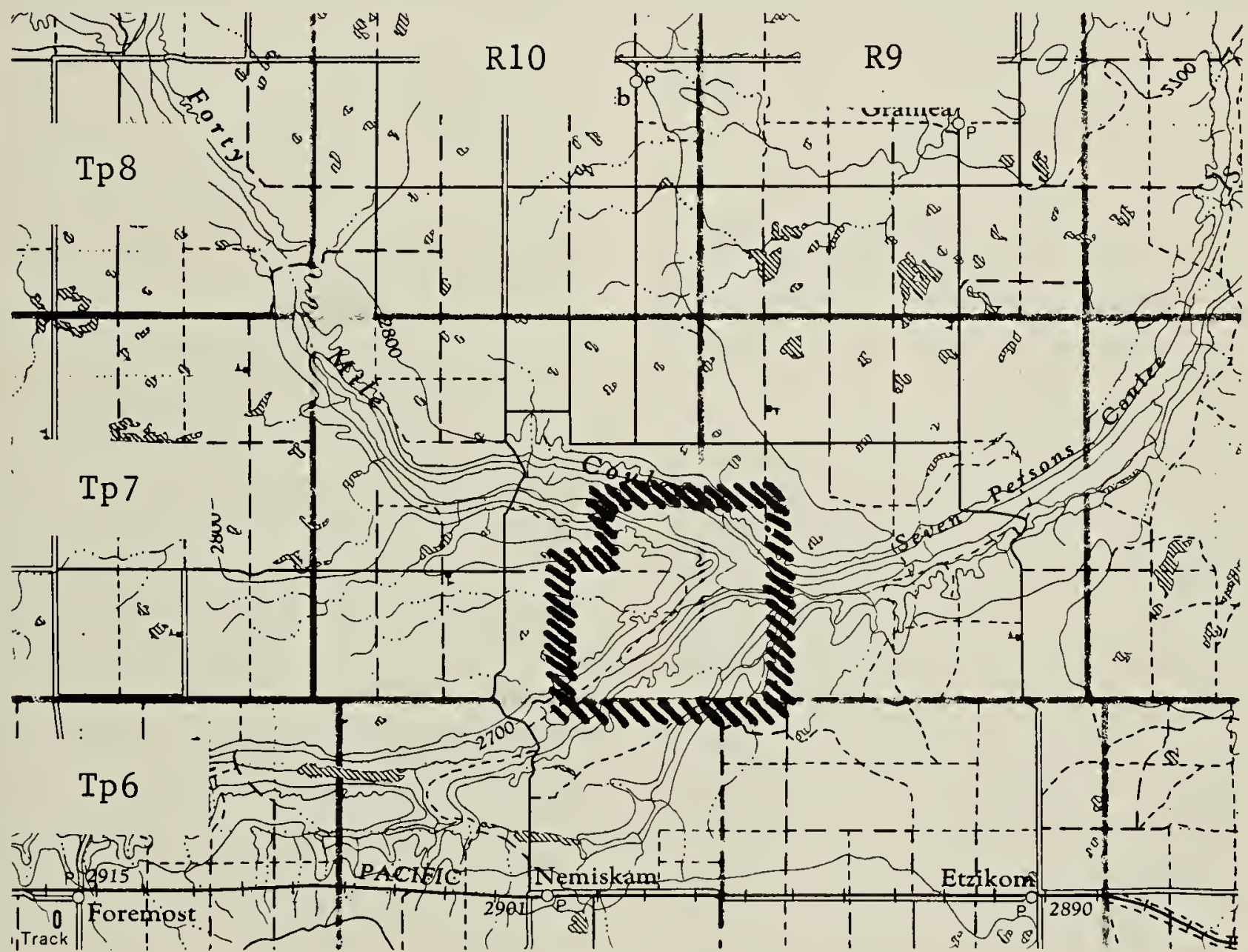

2. Nemiskam, Alberta 


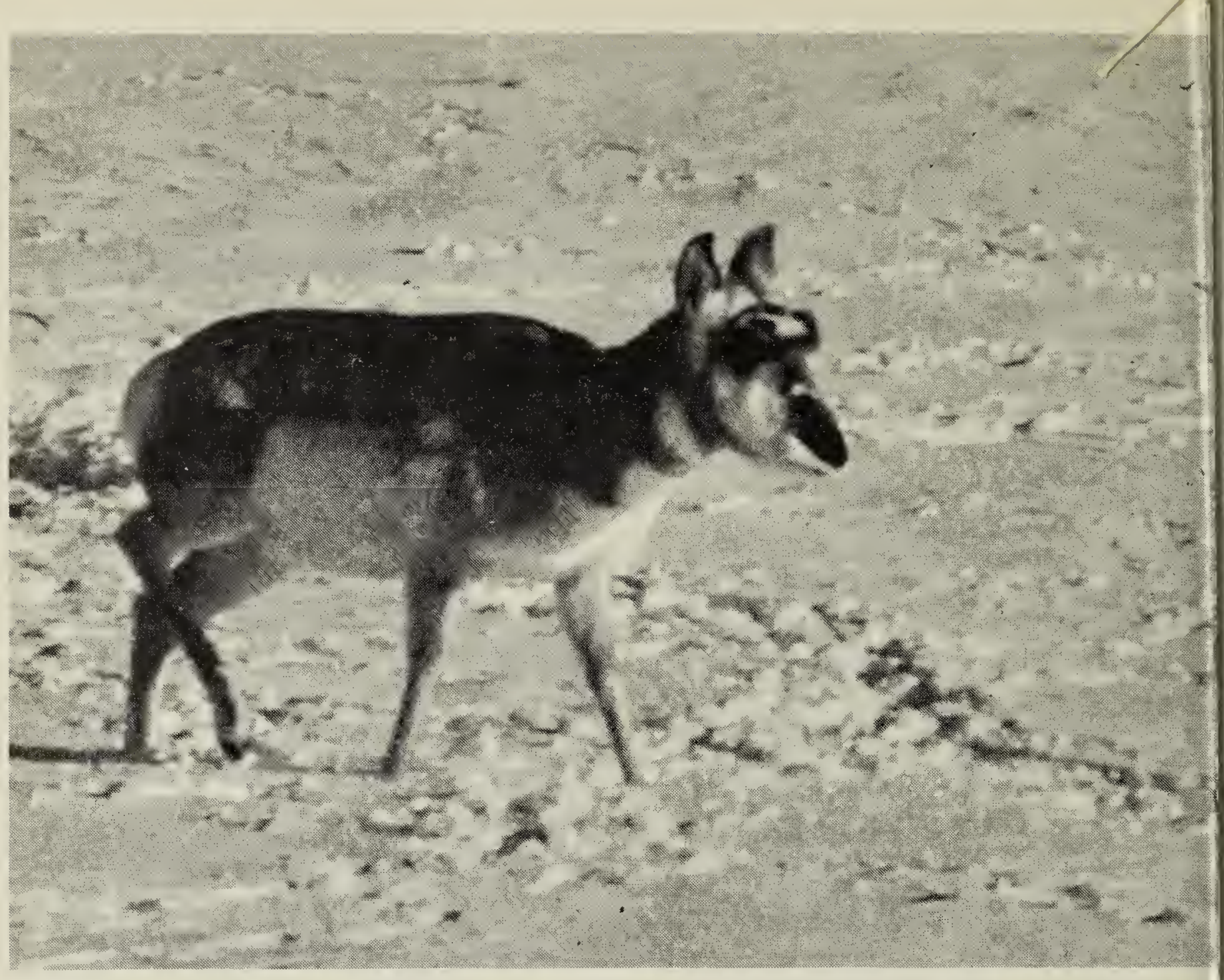

Pronghorns in snow.

Gary W. Seit

three were officially proclaimed as national parks, "with a view to protecting the Prong Horned Antelope and other rare species of wild life" from extinction.

Recovery of the antelope continued to be slow. In 1924, the Canadian population was estimated at 1,400 , in 1925 at 1,327 and in 1933, as 2,400 antelope. In spite of a transient setback in the winter of 1935-36, antelope then began to increase rapidly until Anderson in 1938 estimated 15,000 in Alberta alone. Rand's estimate for the two provinces together in 1945 was 30,906 antelope.

I next wrote to Steve Kun, Director of the Planning Branch of Parks Canada. P. A. Bryan of the Property Management Division replied 2-1/2 months later and apologized for the time required to find all the answers to my questions. Mr. Bryan kindly provided copies of the relevant Acts.

The National Parks Act of 1930 (assented to $30 \mathrm{May}, 1930$ ) included most of the parks embodied in the Dominion Forest Reserves and Parks Act of 1927, but specifically excluded three of the former parks. The excluded parks were Fort Howe Park, a 16-acre park within the city of St. John, New Brunswick, and Menissawok Park and Vidal's Point Park in Saskatchewan. Next, the National Parks Amendment Act, 1938 (assented to 24 June, 1938) abolished Wawaskesy National Park, with the general comment "no longer required for park purposes". Finally, the National Parks Amendment Act 1947. (assented to 17 July, 1947) giving the same general reason, abolished both 
Nemiskam Park and Buffalo Park in Alberta. Mr. Bryan kindly supplied a copy of the Spring, 1966, issue of the quarterly staff magazine of the Department of Northern Affairs and National Resources, with a most helpful article on "The parks of yesteryear" by W. F. Lothian (Intercom 9: 13-17, 1966).

Lothian's article told how the formation of the three parks was a response to predictions such as those of W. T. Hornaday that, because of the difficulty of maintaining the species in captivity, the antelope was doomed to extinction unless it was fully and permanently protected in a wild state in its native range. As the antelope increased in southwestern Saskatchewan, Menissawok Park was released for other purposes in 1930 and in 1938 Wawaskesy Park in Alberta was abolished for similar reasons.

Lothian's article gave details on two other parks of interest to me. Buffalo National Park was established on 170 square miles near Wainwright, Alberta in March, 1908, following purchase by the Canadian government of the main surviving remnant of plains bison anywhere. Between 1907 and 1912 , 716 bison, purchased from Michel Pablo, a Montana rancher, were shipped from Ravalli, Montana, to Canadian parks, chiefly Buffalo Park. By 1940, the total increase over the original herd at Buffalo Park was approximately 27,000 , with many shipped to establish adequate numbers in other National Parks. The park operation was concluded in 1940-41 and the bison slaughtered, supposedly because of deterioration of the range from overgrazing, with disease and parasites developing in the animals. The area was immediately converted to military training purposes, though the park was not officially abolished until 1947!
The final park of interest, to my complete amazement, was my childhood swimming place at Katepwa, Saskatchewan! Lothian's article mentioned that Vidal's Point was reserved as a public camping resort in 1902 by the Forestry Branch of the Department of the Interior. It was named for J. F. Vidal, who homesteaded the adjoining quarter section, and was formally established as a Dominion Park in October, 1921. During the last year of its existence as a national park in 1929 , it attracted 17,400 visitors. Its size of only 17 acres did not measure up to the standards set with the new National Parks Act of 1930, so it was abolished. It is now contained within Katepwa Provincial Park.

This information is offered in the hope that it may also prove of interest to others - and to emphasize the need for public vigilance in these matters. In the 1930's, there wasn't a provincial natural history society nor a National and Provincial Parks Association to comment and few seemed even to notice the abandonment of these parks. It is helpful that an Act of Parliament is necessary before a National Park can be abolished but the above account demonstrates that this is not an ironclad guarantee. Nevertheless, I wish to commend the Government of Saskatchewan for their recent legislation, for the first time requiring an act of the legislature before a Provincial Park can be abolished. This makes our provincial parks much more secure.

What a pity that we have had three national grasslands parks, even if of modest size, and a good-sized parklands area for bison - and let them go. If we are to maintain and extend both our national and our provincial park systems in future, public interest and support will be of increasing importance. 